\title{
ETHICAL BEHAVIOUR: FACTORS INFLUENCING INTENTION TO BUY ORGANIC PRODUCTS IN LITHUANIA
}

\author{
Monika Kavaliauske ${ }^{1}$, Simona Ubartaite ${ }^{2}$ \\ ${ }^{1,2}$ Vilnius University, Lithuania \\ cross'refhttp://dx.doi.org/10.5755/j01.em.19.1.4991
}

\begin{abstract}
During the latest decades economical and social problems had a great influence for society in shaping its ethical behaviour. Consumers started to perceive ethical consumption as a tool to lead society to better and healthier world. Therefore, companies have reacted to changing consumer preferences and offered various ethical products. As the importance of ethical products increased, it is crucial to determine the reasons of ethical consumer behaviour and factors influencing it. The researches made in emerging economies (like Lithuania) on ethical consumption are very limited, therefore neither factors influencing ethical consumer behaviour, neither problems limiting it were determined in Lithuania yet. As the term ethical is quite broad, in this study one form of ethical products - organic products were chosen.

The aim of this research was to determine the factors that influence the intention to buy organic products. Based on the models of Tarkiainen, Sundqvist (2005), Ahmad, Juhdi (2010) and Zhen, Mansori (2012), the research model was developed. It identified the influence of consumer ethical beliefs, concern about product safety, concern about health, and two moderating variables: product price and product availability, on the intention to buy organic products. Quantative survey was carried out among 406 Lithuanian respondents.
\end{abstract}

Paper type: Research paper.

Keywords: organic, ethical, intention to buy.

JEL Classification: M14, M31, Q57.

\section{Introduction}

In recent decades, the role of ethical consumer goods rose as changing people's habits when selecting everyday products. More and more people began to base their buying habits on ethical values and to choose environmentally friendly products buying them from companies that comply with labor standards, provide favorable working conditions for employees and promote fundamental human rights.

Therefore the aim of this research was to determine the factors that influence the intention to buy organic products. Based on the models of Tarkiainen, Sundqvist (2005), Ahmad, Juhdi (2010) and Zhen, Mansori (2012), the research model was developed. It identified the influence of consumer ethical beliefs, concern about product safety, concern about health, and two moderating variables: product price and product availability, on the intention to buy organic products.

\section{Literature review}

The term "ethical consumption" still has no generally recognized and accepted definition (Romu, 2009). According to Crane (2001), and ethical product consists of many aspects that may have an impact on brand choice, like: product safety, product impact on the environment, workers' conditions, discrimination, fair price, and similar. The concepts of "Ethical" researchers perceive and interpret differently, making it difficult to define what ethical consumption is. Smith (1990) defines the ethical purchase as an individual moral decision and buying behavior expression. Crane (2001) argues that the main essence of the concept of ethical consumption is conscious and 
deliberate decision to choose a particular product based on consumers personal beliefs and values. Cooper-Martin and Holbrook define ethical consumer behavior as consumers' decision to procure goods or consume, based on ethical values and concerns about ethical issues (1993). In his scientific work Romu (2009) also confirms the importance of morality, stressing that ethical consumption is a mean to express ones moral obligations. According to Barnett et al. (2005), this moral obligation can be seen as a human image, or part of it.

Adams and Rainsborough say that ethical consumption is an ideology that seeks not to any harm to the environment, to keep up with the fair trade principles and to contribute to the working conditions, al well as animal and human health (2008). Tallontire (2001) confirms this notion, arguing that ethical consumption concept consists of three main elements, namely environmental, animal rights and welfare, and human rights, covering working conditions and fair trade. Although there is no well-defined and uniform use of ethical consumption, the analysis of the scientific literature revealed that most of the authors describe the use of a similar ethical sense. In this paper, ethical consumption will be identified as consumption, which is based on ethical values and problems of choice of goods or services. The ethical issues include the willingness to contribute to the reduction of social and environmental problems.

Very often ethical products are named as organic products because term and indentification sign „Organics“ for most users is associated with the issues in both social and environmental aspects. A study conducted during Makatouni (2002) identified four broad categories, as most consumers perceive and define organic products. Organic food is perceived by its composition (no harmful, modified ingredients are used), method of production (food is grown only in natural conditions with minimal impact to the environment), represented values (safe and healthy) and even social class (upper and medium) (Michaelidou, Hassan, 2008; Davis et al., 1995). On the basis of studies, one of the main motivators in choosing ethical products is the values with which people associate organic products (Makatouti, 2002; Michaelidou, Hassan, 2008; Kraft, Goodel, 1993) and the main value which drives people opt for organic food is its health and safety.

\section{Factors influencing intention to buy organic products}

\section{Ethics}

In terms of an organic purchase of goods, the most often consumers identify and associate organic goods with ethical ones and base their purchase decision on the environmental values (Browne, 2000). Lindeman and Väänänen (2000) explained that the reasons to choose organic products fall into three dimensions: ecological, political and religious motives. According to the authors, organic motives reflect an interest in animal health and environmental safety, and political - in the country of origin and human rights, while religious reasons - in the food acceptability according consumer religion. The research results revealed that concerns about environmental problems had the greatest and most important influence on the choice for organic goods; political considerations have also had a significant positive impact on organic goods. Meanwhile, religious motives are the weakest (Lindeman and Väänänen, 2000).

Authors relate organic product consumption and purchase to people ethics through personal values and moral beliefs, commitments (Honkanen, 2006; Michaelidou, Hassan, 2010). In the scientific literature (Ferrell, Gresham, 1985; Hunt, Vitello 1993; Shaw, Clarke, 1999; Vitelli, Singhapakd, Thomas, 2001) it is also emphasized that certain consumer beliefs and attitudes have a significant impact on consumer behavior. Based on these results authors argue that the promotion of ethical values, such as caring for animals, the desire to reduce the exploitation of farms are directly linked with a positive attitude towards organic product. In addition, compared with the traditional buyers, customers, consuming organic producs are more likely to engage in environmental activities: buy environmentally friendly, ethical, fair trade products and to avoid buying non-ethical products (Honkanen, 2006; McEachern, McClean, 2002; Carrigan, Attalla, 2001).

According to Grunert and Juhl (1995) there is a strong connection between the decision to buy organic products and consumer concern for the environment - these consumers tend to choose 
organic food. This is confirmed by Loureiro et al. (2001), which found that consumers buying the organic fruits are more likely to take interest in the environment and healthy food. Durham and Andrade (2005) suggest that consumer attitudes about health, the environment are one of the main factors influencing consumers' choise for organic products.

\section{Health}

Most of the research, analyzed the motivation of consumers to buy, the main reasons to choose organic products include social and cultural factors as: price, product quality and personal factors (such as emotions and concerns about health) (Hughner, 2007). The studies analyzed consumers' perception of organic food, also attitudes and factors influencing the purchase of goods, and concluded that most consumers prefer organic products due to high concerns about their health (Davies et al., 1995; Foster et al., 1997). A study conducted by Michaelidou and Hassan (2008) concluded that the promotion of a healthy lifestyle has a positive influence on choosing ethical products, including organic ones. Such users tend to choose high-quality, nutritious and healthy food (Michaelidou and Hassan (2008). They look more favorably on organic food being aware of it as healthy and nutritious (Rembiakowska, 2007). Magnusson et al. (2003) confirmed in his investigation, that consumers with rather high health concerns intended to choose organic products instead of usual everyday products.

The opposite view is shared by Tarkianen, Sundqvist (2005) whose study did not find a statistically significant link between health concerns and intention to buy organic products. They argue that concerns about health make the weakest impact on the consumer decision to purchase. Results of the research in New Zealand suggested that consumers are the most affected by health concerns and interest in environmental issues, while in Denmark the intention to buy organic products was mainly influenced by consumers' concerns about the environment (Salleh et al., 2010).

\section{Safety}

Food security is crucial as consumers search for food without chemicals, genetically modified organisms (Michaelidou, Hassan, 2008). Investigation by Michelidou and Hassan confirmed that this consumer concern about health is one of the most important factors influencing consumers' buying decision. Rimal, Moon and Balasubramanian (2005) performed studies in England which revealed that the most important factor in having a major impact on the intention to buy organic products is a concern of the product composition.

According to Hammit and Williams (2006), consumers who choose to buy organic products, tend to believe that these products due to their composition are healthier and less dangerous. This is confirmed by Krystallis et al. (2006), which state that consumers who buy organic products are much more likely to pay more for these products simply because they believe organic products are much healthier. The survey, which interviewed about 3,000 students in Finland, it was confirmed that consumers chose to buy organic food because they think that the food is healthier than conventional products (Krystallis et al., 2006).

Other authors confirm Michelidou findings arguing that concerns about the composition of products is an important factor in the purchase process, but not always the direct determinant of the purchase as only the intention to buy (Turkiainen and Sundqvist, 2005). On the other hand, although these authors emphasize the importance of food security, the intention to buy organic products, according to Shaharudin (2010), has a statistically very small impact on consumer purchasing decisions. Concern for the health factor has a greater impact for the purchase of organic products over concerns about the food safety.

\section{Price}

Price is one of the possible factors that influence the choice of organic products. However, diferent studies give different opinions. Hughner (2005) argues that price is an essential component 
of a negative impact on both the organic food purchase and frequency of purchase. People tend to buy less and less organic ingredients, if the price is relatively high, and higher than the normal everyday products (Briz \& Ward, 2009). Padel and Foster (2005), Hughner (2007), Zanoli, Naspetti (2002) argue that the higher price of organic ingredients is one of the main reasons forcing consumers to refuse to buy organic products.

The opposite view is shared Michaelidou and Hassan (2008), and the Tarkiainen Sundqvist (2005). Studies do not indicate any information that the price can have a statistically significant influence on consumer buying process (Michaelidou and Hassan, 2008; Tarkiainen and Sundqvist, 2005), arguing that, although concerns about the environment can be one of the essential factors influencing consumer interest and purchase organic products, but if the prices are not acceptable for the consumer and he cannot control the situation in the purchase, price and product availability becomes statistically significant factor not to buy organic ingredients (Tarkiainen, Sundqvis, 2005; Uusitalo, Outi, Oksanen, 2004).

\section{Conceptual model}

The aim of the reseach was to identify the factors that determine the intention to buy organic goods in Lithuanian market, but the analysis of the scientific literature found that most of the authors distinguish positive and negative ethical consumption. To assess the consumer's intention to buy, this research seek to identify the factors leading to positive purchase of organic products consumers' desire for choose and buy organic products, thus contributing to the enhancement of ethical consumption.

Key factors included in the model are: importance of the price, consumers concern about their health and product composition, consumer ethics, availability of products on the market, and demographic factors (included as moderating factor).

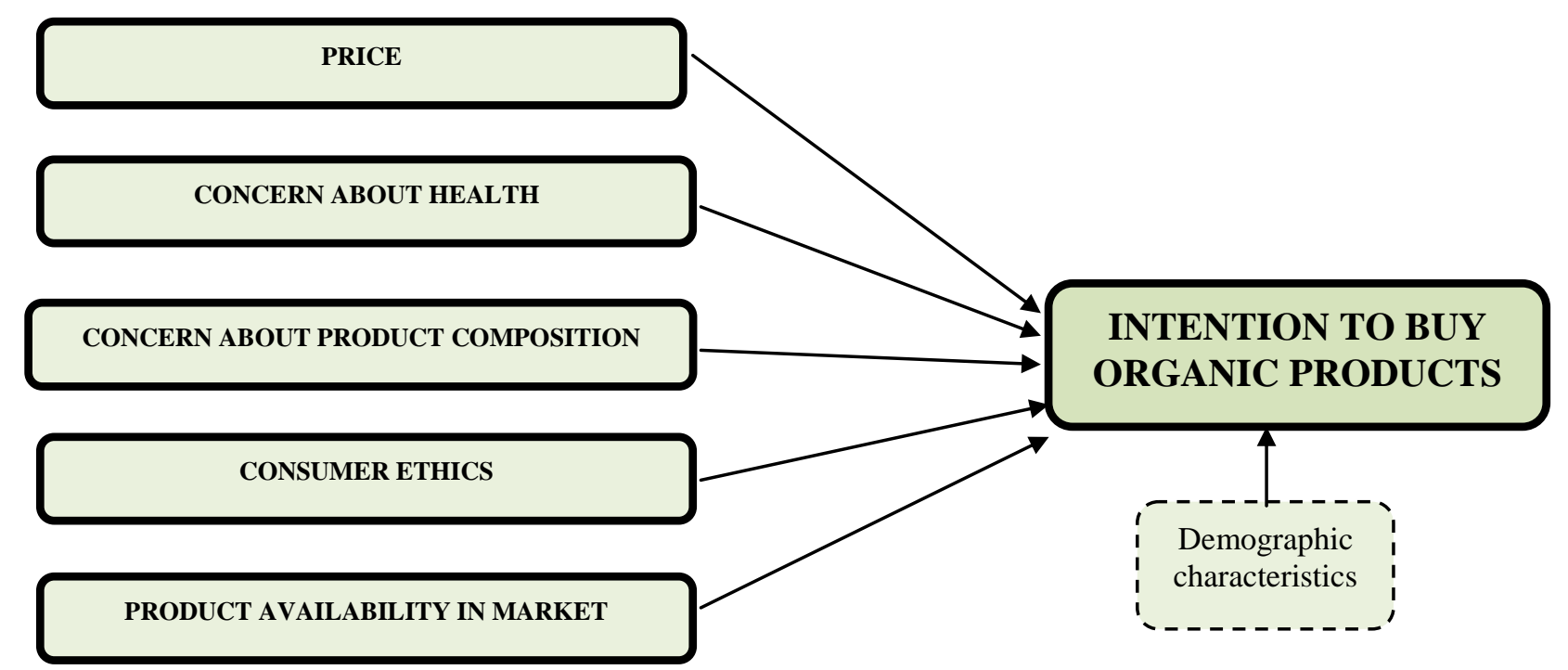

Figure 1. Conceptual model

In order to determine the factors influencing consumers' intention to buy organic products, and verify the effect on relationships five hypotheses have been formed.

Although most of the authors argue that health is one of the most important factors influencing an organic purchase of goods (Davies et al., 1995; Foster et al., 1997; Michaelidou, Hassan, 2008). But the scientific literature also prevails in the opposite opinion that health concerns, or health factors have the least impact on the purchase of goods organically (Tarkianen, Sundqvist, 2005), so in this opinion discrepancy, this paper hypothesizes that: products.

H1: Consumer concerns about health have a positive impact on the intention to buy organic 
While most authors agree that food security is an important factor influencing the intention to buy organic products, some authors argue that this factor is not statistically significant. Under this assumption, we hypothesize that in Lithuania:

H2: Consumer concern about food safety has a positive influence on consumers' intention to buy organic products.

The Lithuanian population has no significant religious food restrictions, therefore in this reseach ethics is defined as choice of organic goods excluding religious motives. Therefore, the study used consumer concerns only about environmental and social problems to examine the importance of consumers' ethics on intention to buy organic products. products.

H3: Consumer ethical issues have a significant impact on the intention to buy organic

The product price and availability are two of the factors included in the user's behavioral control. Based on the scientific literature, it was analyzed that both product price and product availability may be limit by the consumers control and thus influences the decision to buy. For these reasons, the model distinguished both price and product availability factors.

H4: Price has a negative effect on the intention to buy organic products. products.

H5: Organic products availability has a significant impact on the intention to buy organic

\section{Methodology}

Since the topic of ethical products in Lithuania and the world is still relatively new, and studies analyzing organic products market in Lithuania are not available, it is important to consider the fact that there is no information about total number of consumers willing to buy organic products in Lithuania. Therfore, the survey sample was selected using non-probability snowball sampling, which was distributed by the surveyed respondents to consumers with similar properties as they are.

In order to evaluate the consumer's intention to buy organic products, questionnaires based on Tarkiainen, Sundqvist (2005), Ahmad, Juhdi (2010) and Zhen, Mansori (2012) were used. Questioning procedure respondent presented a fixed set of questions. Survey was developed with the principle of closed questions. Most of the questionnaire was made using a 7-point Likert scale where point 1 corresponds to the value - strongly disagree, and point 7 - strongly agree.

Questionnaire represented the model by sets of questions about independant variables: price, care for health, and care for product composition, consumer ethics, and availability in the market on the dependent variable - consumer intention to buy organic produce. Also in order to assess the consumer's demographics, some general questions about the user's demographic characteristics, such as the respondent's education, age, gender, marital status, one family member's average income and education were asked.

In order to determine the statistical reliability of the scales, the questionnaire was tested using Cronbach's alpha coefficient. Sample size was selected to maximize the Lithuanian population reflect the demographic and geographic distribution of the respondents with a 5\% margin of error. In order to produce representative results, the study surveyed 406 respondents.

\section{Results}

Total survey questioned 251 women, representing $61.8 \%$ of all respondents, and 155 men, representing $38.2 \%$ of the respondents. $83.3 \%$ of the already purchased organic products, $3.9 \%$ of them did not, and $12.8 \%$ did not remember of doing so or did not know what is an organic product. The largest share of respondents consists of consumers from 18 to 25 years of age -116 respondents, or $28.6 \%$ of all study participants, and consumers falling into the 26-30 age category -110 respondents (or $27.1 \%$ ).

Assessing the respondents' answers on ethics, health concern, concerns about product composition, respondents were more likely to agree that these factors are important to them in 
choosing organic products. Product availability in the market, on contrary, was perceived as not meaningful (mean of $3.8=$ neither agree nor disagree).

In order to verify the hypotheses Pearson test was used. For the first hypothesis:

H1: Consumer concerns about health has a positive impact on the intention to buy organic products regression analysis was applied, in which the intention to buy is dependent variable and consumer concerns about health is independent variable.

After regression analysis obtained $\mathrm{R}$ Square value is 0.535 . The independent variable explains $53.5 \%$ of the consumer intention to buy organic products. Durbin-Watson coefficient is equal to 2.008. $F$ value is 465.379. Sig-value $<0.05$ indicates that the independent variable affect the dependent variable and regression analysis statistically reliable. Therefore hypothesis 1 is confirmed.

Table 1. Model summary

\begin{tabular}{|c|c|c|c|c|c|}
\hline Model & R & R square & Ajusted R square & Standard deviation & Durbin-Watson \\
\hline 1 & $.732^{\mathrm{a}}$ & .535 & .534 & .72915 & 2.008 \\
\hline
\end{tabular}

a. Predictors: (Constant), concern about health

b. Dependent Variable: intention to buy

Table 2. ANOVA

\begin{tabular}{|l|l|c|c|c|c|c|}
\hline \multicolumn{2}{|c|}{ Model } & Sums square & df & Mean square & F & Sig. \\
\hline \multirow{3}{*}{$\mathbf{1}$} & Regression & 247.426 & 1 & 247.426 & 465.379 & $.000^{\mathrm{a}}$ \\
\cline { 2 - 8 } & Residual & 214.792 & 404 & .532 & & \\
& Total & 462.218 & 405 & & & \\
\hline
\end{tabular}

a. Predictors: (Constant): concern about health

b. Dependent Variable: intention to buy

After the correlation analysis, the obtained p-value less than 0.05 , Pearson coefficient value is 0.732 , so the relation between the consumer and the consumer's intention to purchase health concerns statistically significant. Thus, the more consumers are interested in / are concerned about their health, the more they tend to choose organic produce.

Table 3. Correlation

\begin{tabular}{|c|l|c|c|}
\cline { 3 - 4 } \multicolumn{2}{|c|}{} & intention to buy & concern about health \\
\hline \multirow{3}{*}{ intention to buy } & Pearson correlation & 1 & $.732^{* *}$ \\
\cline { 2 - 4 } & Sig. (1-tailed) & & .000 \\
\cline { 2 - 4 } & $\mathbf{N}$ & 406 & 406 \\
\hline
\end{tabular}

** Correlation significant 0.01 (1-tailed).

H2: Consumer concern about food safety has a positive influence on consumers' intention to buy organic products.

After regression analysis obtained R Square value is 0.364 . The independent variable explains $36.4 \%$ of the consumer intention to buy organic products. Durbin-Watson coefficient is equal to 1.701. F value is 231.205. Sig-value $<0.05$ indicates that the independent variable affect the dependent variable and regression analysis statistically reliable. Therefore hypothesis 2 is confirmed.

Table 4. Model summary

\begin{tabular}{|c|c|c|c|c|c|}
\hline Model & R & R square & Ajusted R square & Standard deviation & Durbin-Watson \\
\hline 1 & $.603^{\mathrm{a}}$ & .364 & .362 & .85303 & 1.701 \\
\hline
\end{tabular}

a. Predictors: (Constant), product composition

b. Dependent Variable: intention to buy 
Table 5. ANOVA

\begin{tabular}{|c|l|c|c|c|c|c|}
\hline \multicolumn{2}{|c|}{ Model } & Sums square & df & Mean square & F & Sig. \\
\hline \multirow{3}{*}{1} & Regression & 168.240 & 1 & 168.240 & 231.205 & $.000^{\mathrm{a}}$ \\
\cline { 2 - 7 } & Residual & 293.978 & 404 & .728 & & \\
\cline { 2 - 7 } & Total & 462.218 & 405 & & & \\
\hline
\end{tabular}

a. Predictors: (Constant), product composition

b. Dependent Variable: intention to buy

Sig-value is $<0.05$, therefore, the relationship between the two variables statistically significant. Correlation strong enough $(\mathrm{r}=0.603)$, and it can be stated that as consumers are more interested in product composition, the more likely they are going to buy organic products.

Table 6. Correlation

\begin{tabular}{|l|l|c|c|}
\cline { 3 - 3 } \multicolumn{2}{c|}{} & \multicolumn{1}{c|}{ intention to buy } & product composition \\
\hline \multirow{3}{*}{ intention to buy } & Pearson correlation & 1 & $.603^{* * *}$ \\
\cline { 2 - 4 } & Sig. (1-tailed) & & .000 \\
\cline { 2 - 4 } & $\mathbf{N}$ & 406 & 406 \\
\hline
\end{tabular}

** Correlation significant 0.01 (1-tailed).

H3: Consumer ethical issues have a significant impact on the intention to buy organic products.

After regression analysis obtained R Square value is 0.562 . The independent variable explains $56.2 \%$ of the consumer intention to buy organic products. Durbin-Watson coefficient is equal to 1.944. F value is 519.044. Sig-value $<0.05$ indicates that the independent variable affect the dependent variable and regression analysis statistically reliable. Therefore hypothesis 3 is confirmed.

Table 7. Model summary

\begin{tabular}{|c|c|c|c|c|c|}
\hline Model & R & R square & Ajusted R square & Standard deviation & Durbin-Watson \\
\hline 1 & $.750^{\mathrm{a}}$ & .562 & .561 & .70764 & 1.944 \\
\hline
\end{tabular}

a. Predictors: (Constant), ethics

b. Dependent Variable: intention to buy

Table 8. ANOVA

\begin{tabular}{|l|l|c|c|c|c|c|}
\hline \multicolumn{2}{|c|}{ Model } & Sums square & df & Mean square & F & Sig. \\
\hline \multirow{4}{*}{1} & Regression & 259.913 & 1 & 259.913 & 519.044 & $.000^{\mathrm{a}}$ \\
\cline { 2 - 7 } & Residual & 202.304 & 404 & .501 & & \\
\cline { 2 - 7 } & Total & 462.218 & 405 & & & \\
\hline
\end{tabular}

a. Predictors: (Constant), ethics

b. Dependent Variable: intention to buy

Applied Pearson test also confirms the hypothesis: The coefficient 0.750 shows a high correlation between the consumer ethics and intention to buy organic products. Sig $<0.05$ indicates that the data obtained is statistically significant, therefore the more ethical / more interested in ethical problems are the consumers, the more likely they are going to buy organic products.

Table 9. Correlation

\begin{tabular}{|l|l|c|c|}
\cline { 3 - 4 } \multicolumn{2}{c|}{} & ethics & intention to buy \\
\hline \multirow{3}{*}{ intention to buy } & Pearson correlation & $.750^{* *}$ & 1 \\
\cline { 2 - 4 } & Sig. (1-tailed) & .000 & 406 \\
\cline { 2 - 4 } & N & 406 & 4 \\
\hline
\end{tabular}

** Correlation significant 0.01 (1-tailed). 
H4: Price has a negative effect on the intention to buy organic products.

After regression analysis it was determined that price sensitivity explains $27.2 \%$ of the dependent variable. Durbin Watson value is 1.602 . Sig-value $<0.05$ indicates that the independent variable affect the dependent variable and regression analysis of statistically reliable. $F$ value is 152.114 .

The results showed that the consumer perceive price of organic products not as high, but as reasonable. So the variable of the price can be defined an affordable and low prices. Average price evaluation value was 4.51 , indicating that the vast majority of respondents say that price of organic products is affordable. Therefore, it can be concluded, that an organic product price has a positive effect on the intention to buy organic products. Hypothesis 4 is rejected.

Table 10. Model summary

\begin{tabular}{|c|c|c|c|c|c|}
\hline Model & R & R square & Ajusted R square & Standard deviation & Durbin-Watson \\
\hline 1 & $.523^{\mathrm{a}}$ & .274 & .272 & .91168 & 1.602 \\
\hline
\end{tabular}

a. Predictors: (Constant), price

b. Dependent Variable: intention to buy

Table 11. ANOVA

\begin{tabular}{|c|l|c|c|c|c|c|}
\hline \multicolumn{2}{|c|}{ Model } & Sums square & df & Mean square & F & Sig. \\
\hline \multirow{3}{*}{1} & Regression & 126.430 & 1 & 126.430 & 152.114 & $.000^{\mathrm{a}}$ \\
\cline { 2 - 7 } & Residual & 335.788 & 404 & .831 & & \\
\cline { 2 - 7 } & Total & 462.218 & 405 & & & \\
\hline
\end{tabular}

a. Predictors: (Constant), price

b. Dependent Variable: intention to buy

Set up more accurate relation between price and the intention to buy organic products Pearson coefficient was calculated. Statistically significant $(p<0.05)$ correlation $(r=0.523)$ between the two variables was found.

Table 12. Correlation

\begin{tabular}{|l|l|c|c|}
\cline { 3 - 4 } \multicolumn{2}{c|}{} & intention to buy & \multicolumn{1}{c|}{ price } \\
\hline \multirow{3}{*}{ intention to buy } & Pearson correlation & 1 & $.523^{* * *}$ \\
\cline { 2 - 4 } & Sig. (1-tailed) & & .000 \\
\cline { 2 - 4 } & $\mathbf{N}$ & 406 & 406 \\
\hline
\end{tabular}

** Correlation significant 0.01 (1-tailed).

In case of discrepancy between the results of the work and the findings of the other authors additional correlation analysis was carried out including price importance when buying intent to purchase construct. The results again confirmed that, despite people are price sensitive while choosing the products (response mean $=4.5$ ), when it comes to purchase of organic goods, the price factor is not influential. Sig $<0.05$, Pearson coefficient value indicates a weak correlation between these two factors $(0.234)$.

Table 13. Correlation

\begin{tabular}{|c|c|c|c|}
\hline & & $\begin{array}{l}\text { Price is very important } \\
\text { when I choose product }\end{array}$ & $\begin{array}{c}\text { intention to } \\
\text { buy }\end{array}$ \\
\hline \multirow{3}{*}{ intention to buy } & Pearson correlation & $.234^{* *}$ & 1 \\
\hline & Sig. (1-tailed) & .000 & \\
\hline & $\mathbf{N}$ & 406 & 406 \\
\hline
\end{tabular}

** Correlation significant 0.01 (1-tailed). 
H5: Organic products availability has a significant impact on the intention to buy organic products.

Multiple regression analysis shows that the availability of organic products on the market did not have statistically significant impact on consumers' intention to buy organic products. Sig received value equal to $0.639>0.05$. Thus, the hypothesis 5 is rejected.

Table 14. Model summary

\begin{tabular}{|c|c|c|c|c|c|}
\hline Model & R & R square & Ajusted R square & Standard deviation & Durbin-Watson \\
\hline 1 & $.023^{\mathrm{a}}$ & .001 & -.002 & 1.06934 & 1.625 \\
\hline
\end{tabular}

a. Predictors: (Constant), availability in the market

b. Dependent Variable: intention to buy

Table 15. ANOVA

\begin{tabular}{|l|l|c|c|c|c|c|}
\hline \multicolumn{2}{|c|}{ Model } & Sums square & df & Mean square & F & Sig. \\
\hline \multirow{3}{*}{1} & Regression & .252 & 1 & .252 & .220 & $.639^{\mathrm{a}}$ \\
\cline { 2 - 7 } & Residual & 461.966 & 404 & 1.143 & & \\
\cline { 2 - 7 } & Total & 462.218 & 405 & & & \\
\hline
\end{tabular}

a. Predictors: (Constant), availability in the market

b. Dependent Variable: intention to buy

In order to determine the relationship between the independent variables on consumer ethics, consumer concerns about health, product composition, price, and market accessibility and dependent variable - consumer intention to buy organic products, multiparametrical analysis was carried out.

$\mathrm{R}$ Square value was 0.702 . Hence independent variables explained $70.2 \%$ of the respondents intention to buy organic products. Sig-value $<0.05$ indicates that the independent variables affect the dependent variable. Durbin-Watson factor of 1.776. This value is within the 1.5 and 2.5 range of values, so we can say that the variables are independent and do not correlate with each other.

Coefficients table shows that all the variables except for the evaluation of product composition affects the independent variable. After analysis, the regression equation was formed to explain the factors that influence consumers' intention to buy organic products.

$Y=0.871+0.340 x$ ethics $+0.373 x$ health concern $+0.039 x$ product composition $+0.146 x$ price $-0.084 x$ availability in market.

Table 16. Model summary

\begin{tabular}{|c|c|c|c|c|}
\hline Model & R & R square & Ajusted R square & Standard deviation \\
\hline 1 & $.838^{\mathrm{a}}$ & .702 & .699 & .58634 \\
\hline
\end{tabular}

a. Predictors: (Constant), availability in the market, health concern, price, ethics, product composition

b. Dependent Variable: intention to buy

Table 17. ANOVA

\begin{tabular}{|c|l|c|c|c|c|c|}
\hline \multicolumn{2}{|c|}{ Model } & Sums square & df & $\begin{array}{c}\text { Mean } \\
\text { square }\end{array}$ & F & Sig. \\
\hline \multirow{3}{*}{1} & Regression & 324.702 & 5 & 64.940 & 188.895 & $.000^{\mathrm{a}}$ \\
\cline { 2 - 7 } & Residual & 137.516 & 400 & .344 & & \\
\cline { 2 - 7 } & Total & 462.218 & 405 & & & \\
\hline
\end{tabular}

a. Predictors: (Constant), availability in market, health concern, price, ethics, product composition

b. Dependent Variable: intention to buy 
Table 18. Coefficients

\begin{tabular}{|c|c|c|c|c|c|c|}
\hline \multirow{2}{*}{\multicolumn{2}{|c|}{ Model }} & \multicolumn{2}{|c|}{$\begin{array}{c}\text { Unstandardized } \\
\text { Coefficients } \\
\end{array}$} & \multirow{2}{*}{$\begin{array}{c}\begin{array}{c}\text { Standardized } \\
\text { Coefficients }\end{array} \\
\text { Beta } \\
\end{array}$} & \multirow[t]{2}{*}{$\mathbf{t}$} & \multirow{2}{*}{ Sig. B } \\
\hline & & $B$ & Std. Error & & & \\
\hline \multirow[t]{6}{*}{1} & (Constant) & .871 & .184 & & 4.729 & .000 \\
\hline & ethics & .340 & .029 & .425 & 11.548 & .000 \\
\hline & health concern & .373 & .042 & .350 & 8.864 & .000 \\
\hline & product composition & .039 & .033 & .045 & 1.159 & .247 \\
\hline & price & .146 & .029 & .188 & 5.025 & .000 \\
\hline & availability in market & -.084 & .023 & -.111 & -3.629 & .000 \\
\hline
\end{tabular}

a. Dependent Variable: intention to buy

Regression analysis shows, that consumers ethics have the greatest impact on intention to purchase organic products $(t=11.548, p<0.01, \beta=0.425)$. Consumer concerns about health has a second order of importance of the selected factors on the intention to buy an organic products $(\mathrm{t}=$ 8.864, $\mathrm{p}<0.01, \beta=0.350)$. Price - the third component selected of the factors influencing the intention to buy $(\mathrm{t}=5.025, \mathrm{p}<0.01, \beta=0.188)$. While Sig $>0.05$, concerns about the product composition factor has a positive effect on the intention to buy $(t=1.159, p=0.247, \beta=0.045)$ the availability of products in the market leads to a negative intention to purchase organic goods. Therefore, it is assumed that the more organic products are available in the market the less consumers intent to buy them $(t=-3.629, p<0.01, \beta=-0.111)$.

Most of the authors come to different findings on the demographic characteristics on consumer intention to buy organic products. With this discrepancy, the study analysis seeks to examine how demographic factors influence consumers' intention to buy organic products. Gender, age, marital status, number of children in the family, the average disposable income per family member, and education indicators were examined. However, the results of statistical analyses found only the significant difference between $26-30$ versus $41-45$ and $31-35$ versus $41-45$ age groups of the respondents. It was concluded that 26-30 age and 31-35 age consumers tend to prefer to buy organic products more than 41-45 age consumers. All other demographic indicators did not have significant influence to buy organic products.

\section{Disscussion}

The research determined that consumer ethical beliefs are the most important for intention to buy organic products. Concern about health also had positive influence on intention to buy, and positively correlated with concern about product composition. These findings revealed that for intention to buy ethical products not only ethical beliefs are important but also the great consumer concern about its health. Further, it was determined that consumers perceive organic products both as healthier, and friendlier for the environment. Although many authors found the price as limiting factor for intention to buy organic products, the results of this research showed different approach. The price was perceived as important factor for buying organic products, but it was perceived as affordable, and price had positive impact on intention to buy organic products. Also research results compared to other authors revealed different impact of product availability for intention to buy it, which was negative. Therefore combining this fact with price, it can be stated that consumers in Lithuania perceive organic products more like luxury goods.

The research revealed the differences between consumer characteristics regarding ethical consumer behaviour. Therefore, business should focus on younger consumers which already have some knowledge about ethical problems and advantages of organic products. To attract other age groups, companies should invest into information communication strategies and consumers education, emphasising on not only environmental aspect but especially the health care issue.

This is one of the first researches made in Lithuania where intention to buy ethical products was analyzed. Research results revealed the importance of ethics in consumer behaviour. Therefore, 
these findings can be the basis for further researches on ethical consumer behaviour with different product categories.

\section{References}

Adams, M., Raisborough, J. (2008). What can Sociology say about FairTrade? Class, Reflexivity and Ethical Consumption. Sociology, 42 (6), 1165-1182. http://dx.doi.org/10.1177/0038038508096939

Ahmad, S. N. B., Juhdi, N. (2010). Organic Food: A Study on Demographic Characteristics and Factors Influencing Purchase Intentions among Consumers in Klang Valley, Malaysia. International Journal of Business and Management, vol. 5, nr. 2.

Browne, A. W., Phil, J. C. H., Hofny-Collins, A.H., Pasiecznik, N. M., Wallace, R. R. (2000). Organic Production and Ethical Trade: Definition, Practice and Links. Food Policy, 25 (1), 69-89. http://dx.doi.org/10.1016/S0306-9192(99)00075-5

Barnett, C., Cloke, P., Clarke, N., Malpass A. (2005). Consuming Ethics: Articulating the Subjects and Spaces of Ethical Consumption. Antipode, 37 (1), 23-45. http://dx.doi.org/10.1111/j.00664812.2005.00472.x

Briz, T., Ward, R. W. (2009). Consumer awareness of organic products in Spain: An application of multinominal logit models. Food Policy, vol. 34, issue 3, 295-304. http://dx.doi.org/10.1016/j.foodpol.2008.11.004

Carrigan, M., Attalla, A. (2001). The Myth of the Ethical Consumer - Do Ethics Matter in PurchaseBehaviour. Journal of Consumer Marketing, 18(7), 560-577. http://dx.doi.org/10.1108/07363760110410263

Clouder, S., Harrison, R. (2005). The effectiveness of ethical consumer behaviour. The ethical consumer, 89104. http://dx.doi.org/10.4135/9781446211991.n7

Davies, A., Titterington, A. J., Cochrane, C. (1995). Who buys organic food? A profile of the purchasers of organic food in Northern Ireland. British Food Journal. 97(10), 17-23. http://dx.doi.org/10.1108/00070709510104303

Cooper-Martin, E., Holbrook, M. B. (1993). Ethical Consumptions Experiences and Ethical Space. Advances in Consumer Research, 20, no. 1, 113-118.

Crane, A. (2001). Unpacking the ethical product. Journal of Business Ethics, 30(4), 361-374. http://dx.doi.org/10.1023/A:1010793013027

Durham, C. A., Andrade, D. (2005, July). Health vs. environmental motivation in organic preferences and purchases. In American Economics Association Annual Meeting, Rhode Island, July, D.

Foster, C., Latacz-Lohmann, U. (1997). From niche to mainstream strategies for the marketing of organic food in Germany and the UK. British Food Journal, vol. 99, no. 8, 275-82. http://dx.doi.org/10.1108/00070709710188336

Grunert, S. C., Juhl, H. J. (1995). Values, environmental attitudes, and buying of organic foods. Journal of Economic Psychology, 16, 39-62. http://dx.doi.org/10.1016/0167-4870(94)00034-8

Hammitt, K., Williams P. (2006). Perceived Risks of Conventional and Organic Produce: Pesticides, Pathogens and Natural Toxins. Risk Analysis Journal, vol. 21 (2), 319-330.

Honkanen, P., Verplanken, B., Olsen, S. O. (2006). Ethical values and motives driving organic food choice. Journal of Consumer Behaviour, 5: 420-430. http://dx.doi.org/10.1002/cb.190

Michaelidou, N., Hassan, L. M. (2007). The role of health consciousness, food safety concern and ethical identity on attitudes and intentions towards organic food. International Journal of Consumer Studies, vol. 32, issue 2, 163-170. http://dx.doi.org/10.1046/j.1470-6431.2002.00199.x

McEachern, M. G., Mcclean, P. (2002). Organic purchasing motivations and attitudes: are they ethical? International Journal of Consumer Studies, 26(2), 85-92.

Hughner, R. S. (2007). Who are organic food consumers? A compilation and review of why people purchase organic food. Journal of Consumer Behaviour, vol. 6, issue 2-3, 94-110. http://dx.doi.org/10.1002/cb.210

Ferrell, O. C., Gresham, L. G. (1985). A Contingency Framework for Understanding Ethical Decision Making in Marketing. Journal of Marketing (Summer), 87-96. http://dx.doi.org/10.2307/1251618 
Hunt, S. D., Vitell, S. J. (1993). The General Theory of Marketing Ethics: A Retrospective and Revision. Ethics in Marketing (Irwin Inc., Homewood, IL), 775-784.

Krystallis, A., Chryssohoidis, G. (2006). Consumers' willingness to pay for organic food products: Factor that affect it and variation per organic product type. British Food Journal, vol. 107, no. 6, 320-343.

Kraft, F.B., Goodell, P.W. (1993). Identifying the health conscious consumer. Journal of Health Care Marketing, 13(3): 18-25.

Lindeman, M., Väänänen, M. (2000). Measurement of ethical food choice motives. Appetite, volume 34, issue 1, 55-59. http://dx.doi.org/10.1006/appe.1999.0293

Loureiro, M. L., McCluskey, J. J. \& Mittelhammer, R. C. (2001). Assessing consumer preferences for organic, eco-labeled, and regular apples. Journal of Agricultural and Resource Economics, 404-416.

Makatouni, A. (2002). What motivates consumers to buy organic food in UK. Food Journal, vol. 104, no. 3/5, 345-53. http://dx.doi.org/10.1108/00070700210425769

Magnusson, M. K., Arvola, A., Hursti, U. K. K., Åberg, L., Sjödén, P. O. (2003). Choice of organic foods is related to perceived consequences for human health and to environmentally friendly behaviour. Appetite, 40(2), 109-117. http://dx.doi.org/10.1016/S0195-6663(03)00002-3

Padel, S., Foster, C. (2005). Exploring the gap between attitudes and behavior. Understanding why consumers buy or do not buy organic food products. British Food Journal, 107(8), 606-625. http://dx.doi.org/10.1108/00070700510611002

Rembiakowska, E. (2007). Quality of plant products from organic agriculture. Journal of Science Food Agriculture, vol. 87, 2757-2762. http://dx.doi.org/10.1002/jsfa.3000

Rimal, A. P., Moon, W., Balasubramanian, S. (2005). Agro-biotechnology and organic food purchase in the United Kingdom. British Food Journal, vol. 107, issue: 2, 84-97. http://dx.doi.org/10.1108/00070700510579162

Romu, H. (2009). Ethical consumption as an identity project - A narrative approach to Finnish ethical consumers' identity construction. On the internet: https://aaltodoc.aalto.fi/handle/123456789/320

Salleh, M. M., Ali, S. M., Harun, E. H., Jalil, M. A., Shaharudin, M. R. (2010). Consumer's Perception and Purchase Intentions towards Organic Food Products: Exploring Attitude among Academician. Canadian Social Science, 6(6), 119-129.

Shaw, D., Clarke, I. (1999). Belief Formation in Ethical Consumer Groups: an Exploratory Study. Marketing Intelligence and Planning, 17(2), 109-119. http://dx.doi.org/10.1108/02634509910260968

Shaharudin (2010). Factors Affecting Purchase Intention of Organic Food in Malaysia's Kedah State. CrossCultural Communication, vol. 6, no. 2, 105-116.

Smith, N. C. (1990). Morality and the Market. Consumer Pressure for Corporate Accountability, Routledge, London, UK.

Tarkianen, A., Sundqvist, S. (2005). Subjective norms, attitudes and intentions of Finnish consumers in buying organic food. British Food Journal, vol. 107, iss: 11, 808-822.

Tallontire, A., Erdenechimeg, R., Blowfield M. (2001). Ethical Consumers and Ethical Trade: A Review of Current Literature. Policy Series 12. Chatham, UK: Natural Resources Institute.

Uusitalo, O., Oksanen, R. (2004). Ethical consumerism: a view from Finland. International Journal of Consumer Studies, 28 (3), 214-221. http://dx.doi.org/10.1111/j.1470-6431.2003.00339.x

Vitell, S. J., Singhapakdi, A., Thomas, J. (2001). Consumer Ethics: An Applicationand Empirical Testing of the Hunt-Vitell Theory of Ethics. Journal of Consumer Marketing, 18 (2), 153-178. http://dx.doi.org/10.1108/07363760110386018

Zanoli R., Naspetti, S. (2002). Consumer motivations in the purchase of organic food. British Food Journal, vol. 104, no. 8, 643-53. http://dx.doi.org/10.1108/00070700210425930

Zhen, J. S. S., Mansori, S. (2012). Young Female Motivations for Purchase of Organic Food in Malaysia. International Journal of Contemporary Business Studies, vol. 3, no. 5, 61-72. 